\title{
An analysis of transformational leadership, talent acquisition and talent retention of engineers at an energy provider in South Africa
}

\begin{tabular}{|c|c|}
\hline \multicolumn{2}{|c|}{$\begin{array}{l}\text { Authors: } \\
\text { Chuma A. Mangisa }{ }^{1} \\
\text { Cecile M. Schultz } \\
\text { Lize van Hoek }\end{array}$} \\
\hline \multicolumn{2}{|c|}{$\begin{array}{l}\text { Affiliations: } \\
\text { 'Department of People } \\
\text { Management and } \\
\text { Development, Management } \\
\text { Sciences, Tshwane University } \\
\text { of Technology, Pretoria, } \\
\text { South Africa }\end{array}$} \\
\hline \multicolumn{2}{|c|}{$\begin{array}{l}\text { Corresponding author: } \\
\text { Chuma Mangisa, } \\
\text { camangisa.cm@gmail.com }\end{array}$} \\
\hline \multicolumn{2}{|c|}{$\begin{array}{l}\text { Dates: } \\
\text { Received: } 23 \text { Mar } 2020 \\
\text { Accepted: } 15 \text { Sept. } 2020 \\
\text { Published: } 21 \text { Dec. } 2020\end{array}$} \\
\hline \multicolumn{2}{|c|}{$\begin{array}{l}\text { How to cite this article: } \\
\text { Mangisa, C.A., Schultz, C.M., } \\
\text { \& Van Hoek, L. (2020). An } \\
\text { analysis of transformational } \\
\text { leadership, talent acquisition } \\
\text { and talent retention of } \\
\text { engineers at an energy } \\
\text { provider in South Africa. SA } \\
\text { Journal of Human Resource } \\
\text { Management/SA Tydskrif vir } \\
\text { Menslikehulpbronbestuur, } \\
\text { 18(0), a1356. https://doi. } \\
\text { org/10.4102/sajhrm. } \\
\text { v18i0.1356 }\end{array}$} \\
\hline \multicolumn{2}{|c|}{$\begin{array}{l}\text { Copyright: } \\
\text { (C) 2020. The Authors } \\
\text { Licensee: AOSIS. This } \\
\text { is licensed under the } \\
\text { Creative Commons } \\
\text { Attribution License. }\end{array}$} \\
\hline \multicolumn{2}{|l|}{ Read online: } \\
\hline 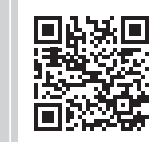 & $\begin{array}{l}\text { Scan this QR } \\
\text { code with your } \\
\text { smart phone or } \\
\text { mobile device } \\
\text { to read online. }\end{array}$ \\
\hline
\end{tabular}

Orientation: Scholars long debated the importance of transformational leadership, talent acquisition and talent retention.

Research purpose: The purpose of this study was to analyse transformational leadership, talent acquisition and talent retention of engineers at Eskom by investigating the demographic differences, relationships and transformational leadership as the mediating variable.

Motivation for the study: Eskom has improved the remuneration of engineers over the years but continued encountering challenges to attract and retain them. The researcher investigated whether the perceived lack of transformational leadership caused the challenges experienced by the organisation.

Research approach/design and method: This was quantitative study, which used conveniencesampling method to obtain 585 completed questionnaires from the engineers.

Main findings: The researcher performed a one-way Anova test to establish if engineers from a gender and educational qualification perspectives were different from each other on the eight sub-factors identified through exploratory factor analysis. The $p$-values were greater than 0.05, meant that there was no statistical difference between genders and between engineers with different educational qualifications. The researcher conducted a post-hoc pairwise test $(p$-values $<0.05)$ on different age groups and results revealed that older respondents ( $31-40$ years of age) had greater positive attitude on the perception of beforeselection, during-selection and development than the younger group (18 - 30 years of age). In addition, the study revealed that transformational leadership mediated the relationship between talent acquisition and retention of engineers.

Practical/managerial implications: The study emphasises that not only salaries are important to attract and retain engineers, but also effective leadership is essential, especially the transformational leadership philosophy.

Contribution/value-add: South Africa has a dearth of engineers. The study results illustrates the importance of transformational leadership philosophy in addressing the challenge the organisation faces. Therefore, the organisation must consider designing programmes to help leaders embrace the transformational leadership philosophy.

Keywords: transformational leadership; talent acquisition; talent retention; mediation; ANOVA test.

\section{Introduction}

George (2015) avows that professional workers are a group of people who are involved in the same kind of work and belong to a specific profession. They often display high levels of expertise and autonomy. George (2015) also contends that these people believe in the self-regulation of their profession and value their profession. George (2015) submits further that these professional workers are very loyal to and identify with both the profession and their organisation.

Therefore, in my view, engineers do fall into the category of people as espoused by above. They command high level of expertise and autonomy, believe in the regulation of their profession and can also be loyal to and identify with profession and their organisation. This group of professionals is critical for the world, in general, and for South Africa, in particular, and should be strategically managed. 
The Chartered Institute of Personnel Development (2018) explains talent management as a process that seeks to attract, identify, develop, engage, retain and deploy individuals who are considered particularly valuable to an organisation. Naidoo, Abarantyne and Rugimbana (2019) see employee retention as the ability to hold onto those employees an organisation wants to keep for longer time than the competitors do. Sequeira, Attupuram and Gopalakrishnan (2015) describe talent acquisition as a process of planning, sourcing, assessing, hiring and on-boarding of qualified and talented individuals into appropriate positions in the organisations.

In an uncomplicated way, Mittal and Dhar (2015) expound transformational leadership as the organisational leader's ability to influence followers' behaviour and self-interest towards organisational goals, performing beyond their duties or fulfilling leaders' expectations.

This study has a particular focus on establishing whether the presence or absence of transformational leadership in the organisation understudy has the mediating effect in attracting and retaining engineers.

\section{Purpose}

The purpose of this study was to analyse transformational leadership, talent acquisition and talent retention of engineers at Eskom by investigating the demographic differences and relationships amongst the variables and to determine if transformational leadership is the mediating variable between talent acquisition and retention.

\section{Literature review}

\section{Transformational leadership}

Downton (1973) first coined the theory of transformational leadership and categorised three leadership tendencies, which are transactional leadership, charismatic leadership and inspirational leadership. However, Burns (1978) further studied and developed it through research (Louw, Muriithi, \& Radloff, 2017). Mittal and Dhar (2015) describe a transformational leader as one who inspires followers to do more than originally expected. They contend that this is performed by raising their level of awareness about the importance and value of designated outcomes and methods of achieving these outcomes, motivating them to transcend beyond their own self-interest for the sake of the team, organisation or larger community and ultimately expanding their portfolio of needs and wants (Mittal \& Dhar, 2015). In agreement with Mittal and Dhar (2015), Khorshid and Pashazadeh (2014) aver that transformational leaders create an atmosphere of trust and motivate employees to work for the organisation beyond their selfinterests.

They argue that it can be categorised into four main dimensions: idealised influence, inspirational motivation, intellectual stimulation and individualised consideration (Mittal \& Dhar, 2015). Idealised influence refers to transformational leaders' ability to influence followers by demonstrating high levels of competence, values and ethical standards and displaying self-confidence to followers in their ability to accomplish organisational tasks, leading followers to respect and admire their leaders (Eberly, Bluhm, Guarana, Avolio, \& Hannah, 2017). Inspirational motivation includes communication, interaction and discussion of a meaningful vision with followers to work towards the organisation's current and future vision; the leader also needs to demonstrate optimism and enthusiasm for that vision and to inspire followers to overcome challenges that may exceed their expectations (Engelen, Gupta, Strenger, \& Brettel, 2015).

Bass and Avolio (eds. 1966) show that leaders displaying intellectual stimulation should carefully examine offers ensuring their suitability; consider different perspectives whilst solving a problem; request for examination of problems from various viewpoints and suggest new ways of how to do something.

From an individualised consideration purview, these two scholars contend that leaders should allocate time for guiding and training their followers; treat members as persons and not as mere members; understand followers as people with different needs and abilities; help others to develop their capabilities (eds. Bass \& Avolio, 1996).

\section{Talent acquisition}

Most people conflate talent acquisition with recruitment and, in fact, the two concepts are very different from each other. Rivera (2012) explains the former as an ongoing cycle of processes related to attracting, sourcing, recruiting and hiring (or placing) employees within an organisation. Seeing that recruitment is part of the talent acquisition process, Devi and Banu (2014) define recruitment as a continuous process, whereby the firm attempts to develop a pool of qualified applicants for the future human resource needs even though specific vacancies do not exist. It is therefore understood that recruitment is part of the talent acquisition process; however, talent management involves talent acquisition; hence, Kibui and Kanyiri (2013) describe talent management to be centred on resourcing, selection, training and development of employees.

In concurrence with Rivera (2012), Kibui and Kanyiri (2013) and Sequeira et al. (2015), as stated earlier, explain talent acquisition as a process of planning, sourcing, assessing, hiring and on-boarding of qualified and talented individuals into appropriate positions in the organisations. It is widely accepted that attracting the most suitable candidates enhances an organisation's ability to deliver excellent results (Meyer, 2016). At the individual level, a significant amount of attention in the strategic human capital literature has been focused on the hiring of stars (Call, Nyberg, \& Thatcher, 2015). In agreement with Call et al. (2015), Kehoe and 
Tzabbar (2015) avow that such hires are suggested to provide firms with a visible increase in human capital that can ultimately be diffused to other employees and leveraged by the firm.

Large-scale human capital acquisition approaches, such as mergers and acquisitions, can also be used to modify a firm's stock of human capital (Chatterji \& Patro, 2014). However, these two academicians opine that this approach involves the acquisition of additional resources than just human capital and tends to be less flexible than lateral hiring approaches (Chatterji \& Patro, 2014).

\section{Talent retention}

Organisations are beginning to realise that employees are key to their success and view employee relationship as mutually beneficial. In line with this statement, Dhanpat, Modau, Lugisani, Mabojane and Phiri (2018) explain that fluctuations in the economy and changes in demographics in businesses locally and abroad have caused organisations to shift their attention towards the retention of staff. It is therefore important that organisations should create effective and deliberate mechanisms to prevent employees from acting on their turnover intentions and end up leaving organisations. Kaur, Mohindru and Pankaj (2013) define turnover intentions as the intention of the employees to quit. According to Better (2015), engineering service firms are facing an ever-shrinking supply of talent. Coupled with an ageing workforce, the problem of having a sufficient supply of competent engineers and project managers is of significant concern (Better, 2015). This challenge in my view warrants organisations to strategically manage these engineers; otherwise, they risk losing their competitive advantage.

In line with Kaur et al. (2013), I can explain talent retention as a process where organisations start creating effective mechanisms to persuade employees to not affect their turnover intentions. These scholars, Dhanpat et al. (2018), agree with Kaur et al. (2013) and maintain that for an organisation to thrive in the changing world of work, there is a need to attract, develop and retain talent with the right skills and knowledge that will enhance organisational effectiveness and efficiency. Naidoo et al. (2019), as stated earlier, assert that employee retention can be better explained as the ability to hold onto those employees an organisation wants to keep for longer time than the competitors do. This statement is very important or else they will leave for what is often said 'greener pastures'.

\section{Research design \\ Research approach}

Bless, Higson-Smith and Sithole (2014) aver that a quantitative research design provides a detailed outline for the testing of the hypothesis, spelled out in clear and definite terms. From a purposive purview, Leedy and Ormrod (2015) profess that quantitative researchers tend to search for explanations and predictions that will extrapolate to other persons and places. The intention, according to Leedy and Ormrod (2015), is to identify relationships amongst two or more variables and then, based on the results, confirm or modify existing theories or practices. Consequently, a quantitative research approach was preferred as the most apposite procedure for this study.

This study could also be characterised as a correlational study. Bless et al. (2014) posit that researchers use a correlational research to make a statement or hypothesis, predicting the relationship between two or more variables. Leedy and Ormrod (2015) concur with Bless et al. (2014) and affirm that correlational research is a statistical investigation of the relationship between two or more variables.

The results obtained in this study will be able to provide a precise description of reality. Therefore, the survey design was correlational as it sought to measure the relationships between three variables (namely transformational leadership, talent acquisition and retention). A cross-sectional design was used to gather the data in order to achieve the specific aims of this study.

\section{Research participants}

A convenience sampling was used, which is part of the non-random sampling methodology. Out of these 2500 engineers employed by the responded organisation, 585 engineers completed the questionnaire. The 585 engineers who completed the questionnaires constituted the sample for this study. The response rate in this particular study was $23 \%$, which is acceptable, and the findings therefore can be extrapolated (Mc Daniel \& Gates, cited by Martin, 2007). A representative sample of engineers could also be confirmed because of the varied nature of the respondents in terms of age, trade, tenure, academic qualifications and their designations.

The respondents' composition is as follows: $99.7 \%$ were on permanent contracts; $68.8 \%$ were males and $31.2 \%$ were females. This study revealed that $45.7 \%$ were between ages of 31 and 40 years, 2.3\% were between ages of 18 and 30 years, $21.8 \%$ were between ages of 41 and 50 years and $10.1 \%$ were 51 years and more. None of the respondents had $<1$ year of service. The results demonstrated that of the 585 respondents, $58.5 \%$ were electrical engineers, $2.6 \%$ were mechanical engineers, $10.0 \%$ were chemical engineers, $4.9 \%$ were civil and structural engineers, $1.3 \%$ were quantity surveyors, $0.5 \%$ were draughtsman and $0.2 \%$ were geologists.

\section{Measuring instruments}

The researcher used two sets of questionnaires. The first set of questionnaire, which was sent to 2500 engineers, was divided into four sections (i.e. biographic data, transformational 
leadership, talent acquisition and talent retention). The transformational leadership and talent retention questionnaires were adapted from Avolio and Bass (2004), Lievens, Van Gert and Coetsier (1997) and Sinha and Sinha (2012), respectively. The researcher extracted certain themes from the literature (Crispin \& Mehler, 2014; Kaiser, 1970; Rivera, 2012) to develop the talent acquisition questionnaire. This particular questionnaire was piloted and it proved to be valid and reliable when subjected to statistical testing. Out of these 2500 engineers, 585 engineers completed the questionnaire. The response rate in this particular study was $23 \%$ and the findings are acceptable and extrapolated as stated earlier.

A principal axis factor analysis with a direct oblimin rotation was performed on the various scales to investigate the groupings of items and their correspondence to the original theoretical scales. This was performed to determine whether the 42 variables could be reduced to a more meaningful set of factors to highlight how transformational leadership is viewed in relation to talent acquisition and retention. Kaiser-Meyer-Olkin (KMO) and Bartlett's test were used and a result of 0.920 was achieved, which is acceptable for sampling adequacy (Kaiser, 1970). Bartlett test of sphericity was significant at $p=0.000$ (Kaiser, 1970).

Theoretically, transformational leadership had four original factors, which are Idealised Influence, Inspirational Motivation, Intellectual Stimulation and Individualised Consideration. However, after exploratory factor analysis (EFA) investigation on these original factors, new sub-actors were identified, which were supervisory stimulation and vision, consideration and positive attitude. The Cronbach alpha coefficients of these sub-factors are supervisory stimulation and vision (0.891), consideration (0.824) and positive attitude (0.824). The reliability coefficients of all these factors are acceptable and reliable because they are higher than 0.4 (Welman, Kruger, \& Mitchell, 2011).

On talent acquisition, theoretically, one factor was intended for talent acquisition. However, factor analysis indicated that a two-factor analysis solution is the best. The factors are before-selection and during-selection and yielded Cronbach alpha coefficients of 0.721 and 0.621 , respectively, which are acceptable and reliable.

On talent retention, factor loadings showed that three clear factors could be identified, which were relationship, reward and development, and yielded Cronbach alpha coefficients of $0.650,0.653$ and 0.750 , respectively, which are acceptable and reliable.

\section{Research procedure and ethical considerations}

As indicated above, this study followed a quantitative approach. The respondent sample was 585 engineers, chosen using a convenience sampling approach as stated earlier. The results were analysed statistically looking at correlation, reliability, analysis of variance (ANOVA), regression, post hoc multi-comparison analysis, regression analysis and bootstrapping.
Ethically, participants were informed of the risks and benefits of participating in this study and how it may affect them. Participant's privacy was protected during the course of this study because their anonymity was preserved when they responded to the electronic questionnaire. The respondents had a choice to either participate in this study or not. Honesty prevailed when reporting the study findings and no misrepresentation or deception took place.

\section{Statistical analysis}

A correlation analysis using Spearman's Rho correlation (Leedy \& Ormrod, 2015) was conducted to determine the relationship between transformational leadership, talent acquisition and talent retention. Regression analysis was used to determine whether transformational leadership is a mediator between talent acquisition and talent retention.

\section{Discussion}

This study focused at Eskom engineers because the leadership felt that something was wrong somewhere. Eskom continued to struggle to attract and retain the engineers despite substantially improving their remuneration.

\section{Categories of engineers in the sample}

Male engineers dominated this study with $68.8 \%$ and females at $31.2 \%$. This confirms the assertion by other scholars that males dominate the engineering field (Peers, 2018; Singh \& Peers, 2019). For example, Smith and Gayles (2018) posit that despite the growing numbers of women earning degrees in engineering, women remain vastly under-represented in engineering fields. As expected, there were more of the electrical engineers than any other field of engineering because Eskom is an electricity generator. Of the 585 respondents, $58.5 \%$ were electrical engineers and the rest were between mechanical, chemical, geologists, draughtsman and quantity surveyors. The results also revealed that $26.2 \%$ had a tenure lying between 1 and 5 years, 36.0\% was between 6 and 10 years, $25.3 \%$ was between 11 and 20 years, $8.3 \%$ was between 21 and 30 years, $4.2 \%$ was 51 years and more. This means that $62.2 \%$ of engineers would have left before they reach a 10 -year tenure. The majority of engineers had bachelor and honour degrees, with only $26.4 \%$ and $1.3 \%$ had masters and doctorate degrees, respectively.

\section{Descriptive statistics}

The following is revealed as regards to Figure 1:

In all the three sub-factors of transformational leadership, the individual mean scores (i.e. 2.17, $2.33 \& 1.76$ ) are lower than the scale midpoint for all the eight sub-factors. This illustrates the fact that engineers were not satisfied with their leaders' lack of supervisory stimulation and vision and consideration and lack of positive attitude.

For talent acquisition factors, engineers showed a positive attitude towards before-selection processes because the individual mean score (2.72) is higher than the midpoint scale 


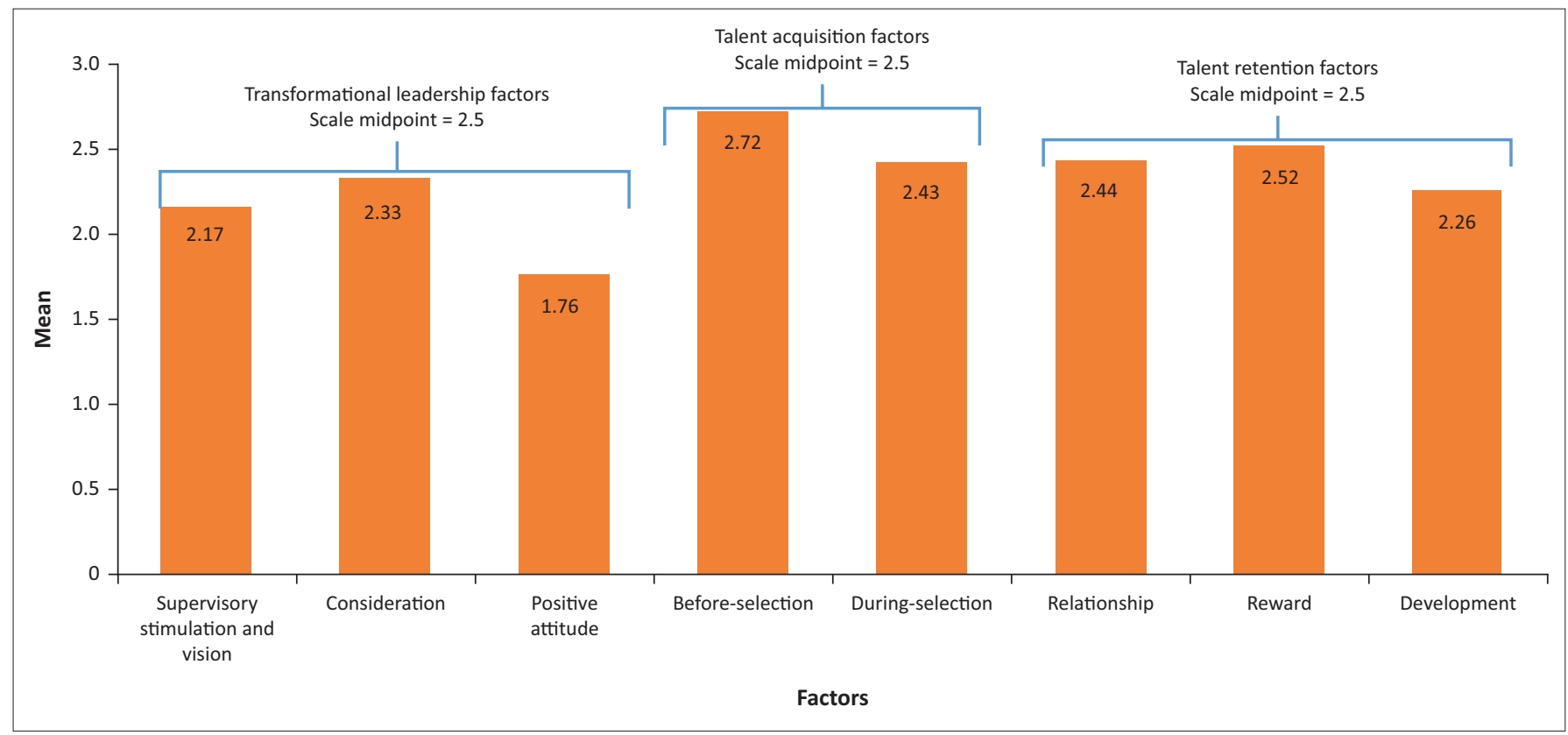

FIGURE 1: Descriptive statistics per factor.

TABLE 1: Analysis of variance comparison between age groups.

\begin{tabular}{|c|c|c|c|c|c|}
\hline ANOVA & SS & $d f$ & MS & $F$-statistics $(f)$ & Sig. ( $p$ value) \\
\hline \multicolumn{6}{|l|}{ Before-selection } \\
\hline Between groups & 27.896 & 2 & 13.948 & 34.176 & 0.000 \\
\hline Within groups & 223.656 & 548 & 0.408 & - & - \\
\hline Total & 251.552 & 550 & - & - & - \\
\hline \multicolumn{6}{|l|}{ During-selection } \\
\hline Between groups & 24.639 & 2 & 12.320 & 35.454 & 0.000 \\
\hline Within groups & 186.254 & 536 & 0.347 & - & - \\
\hline Total & 210.894 & 538 & - & - & - \\
\hline \multicolumn{6}{|l|}{ Relationship } \\
\hline Between groups & 5.231 & 2 & 2.616 & 5.797 & 0.003 \\
\hline Within groups & 236.909 & 525 & 0.451 & - & - \\
\hline Total & 242.141 & 527 & - & - & - \\
\hline \multicolumn{6}{|l|}{ Reward } \\
\hline Between groups & 4.256 & 2 & 2.128 & 4.188 & 0.016 \\
\hline Within groups & 256.085 & 504 & 0.508 & - & - \\
\hline Total & 260.340 & 506 & - & - & - \\
\hline \multicolumn{6}{|l|}{ Development } \\
\hline Between groups & 9.330 & 2 & 4.665 & 9.057 & 0.000 \\
\hline Within groups & 266.788 & 518 & 0.515 & - & - \\
\hline Total & 276.177 & 520 & - & - & - \\
\hline
\end{tabular}

ANOVA, analysis of variance; $\mathrm{df}$, degrees of freedom; MS, mean square; SS, sum of squares.

of 2.5, whereas the during-selection factor stands at 2.43 slightly lower than the midpoint scale, demonstrating unhappiness towards what happens during the selection process.

For talent retention factors, engineers observed poor relationship between them and their managers and no opportunities for development because the relationship and development factors stand at 2.44 and 2.36, respectively, which are less than the scale midpoint of 2.5.

\section{Statistical significant differences}

Analysis of variance was utilised to examime the differences amongst three or more means by comparing the variances (s-squared) both within and across groups (Leedy \& Ormro, 2015). The 5\% level of significance was used. Thus, if the Sig. value $(p)$ is $<0.05$, there is a statistical difference between groups. When there are more than two groups to be compared, a post hoc analysis was added in order to compare the groups pairwise and investigate where there were significant differences.

\section{Analysis of variance for gender}

A one-way ANOVA was performed to establish if males and females were different from each other. No statistical significant difference could be found between males and females for all eight factors. This is because the $p$ values were $>0.05$.

\section{Analysis of variance for age}

A one-way ANOVA between and amongst age groups as depicted in Table 1 was conducted to compare the age groups 
on the factors. In accordance with the $p$ scores in Table 1 , statistical significant differences $(p<0.05)$ between groups were identified for five factors (i.e. before-selection, duringselection, relationship, reward and development).

In Table 2, a post hoc pairwise test was also performed to confirm where the differences occurred between groups. The first statistical significant difference was between ages of 18 and 30 , on the one hand, and 31 and 40 as well as the $41+$ years, on the other hand. On their perception of beforeselection and during-selection $(p<0.05)$, on both scales, older respondents had a more positive attitude than the younger ones (18-30).

The next statistical significant difference was between the age groups of 31-40 and 41+ years on their perception on reward. The older group had a more positive perception towards reward than the younger group.

TABLE 2: Multi-comparison tests between age groups.

\begin{tabular}{|c|c|c|c|c|c|}
\hline \multirow[t]{2}{*}{ Dependent variable } & \multirow{2}{*}{$\begin{array}{c}\text { Mean } \\
\text { difference (I-J) }\end{array}$} & \multirow[t]{2}{*}{ Std. error } & \multirow[t]{2}{*}{ Sig. } & \multicolumn{2}{|c|}{$95 \%$ confidence interval } \\
\hline & & & & Lower bound & Upper bound \\
\hline \multicolumn{6}{|l|}{ Before-selection } \\
\hline \multicolumn{6}{|l|}{$18-30$} \\
\hline $31-40$ & $-0.50889 \dagger$ & 0.06984 & 0.000 & -0.6803 & -0.3375 \\
\hline $41+$ & $-0.56972 \dagger$ & 0.07499 & 0.000 & -0.7538 & -0.3857 \\
\hline \multicolumn{6}{|l|}{$31-40$} \\
\hline $18-30$ & $0.50889 \dagger$ & 0.06984 & 0.000 & 0.3375 & 0.6803 \\
\hline $18-30$ & $0.56972 \dagger$ & 0.07499 & 0.000 & 0.3857 & 0.7538 \\
\hline \multicolumn{6}{|l|}{ During-selection } \\
\hline \multicolumn{6}{|l|}{$18-30$} \\
\hline $31-40$ & $-0.51971 \dagger$ & 0.06519 & 0.000 & -0.6797 & -0.3597 \\
\hline $41+$ & $-0.49668 \dagger$ & 0.07003 & 0.000 & -0.6686 & -0.3248 \\
\hline \multicolumn{6}{|l|}{$31-40$} \\
\hline $18-30$ & $0.51971 \dagger$ & 0.06519 & 0.000 & 0.3597 & 0.6797 \\
\hline $18-30$ & $0.49668 \dagger$ & 0.07003 & 0.000 & 0.3248 & 0.6686 \\
\hline \multicolumn{6}{|l|}{ Relationship } \\
\hline \multicolumn{6}{|l|}{$18-30$} \\
\hline $31-40$ & $-0.22527 \dagger$ & 0.07490 & 0.011 & -0.4091 & -0.0414 \\
\hline $41+$ & $-0.25183 \dagger$ & 0.08070 & 0.008 & -0.4499 & -0.0537 \\
\hline \multicolumn{6}{|l|}{$31-40$} \\
\hline $18-30$ & $0.22527 \dagger$ & 0.07490 & 0.011 & 0.0414 & 0.4091 \\
\hline \multicolumn{6}{|l|}{$41+$} \\
\hline $18-30$ & $0.25183 \dagger$ & 0.08070 & 0.008 & 0.0537 & 0.4499 \\
\hline \multicolumn{6}{|l|}{$18-30$} \\
\hline $41+$ & $-0.21098 \dagger$ & 0.07312 & 0.016 & -0.3905 & -0.0315 \\
\hline $31-40$ & $0.21098 \dagger$ & 0.07312 & 0.016 & 0.0315 & 0.3905 \\
\hline \multicolumn{6}{|l|}{ Development } \\
\hline \multicolumn{6}{|l|}{$18-30$} \\
\hline $31-40$ & $-0.22142 \dagger$ & 0.08110 & 0.025 & -0.4205 & -0.0223 \\
\hline $18-30$ & $0.22142 \dagger$ & 0.08110 & 0.025 & 0.0223 & 0.4205 \\
\hline \multicolumn{6}{|l|}{$41+$} \\
\hline $18-30$ & $0.37051 \dagger$ & 0.08707 & 0.000 & 0.1568 & 0.5842 \\
\hline
\end{tabular}

$\dagger$, The mean difference is significant at the 0.05 level.

TABLE 3: Analysis of variance comparison between tenure groups.

\begin{tabular}{|c|c|c|c|c|c|}
\hline ANOVA & SS & $d f$ & MS & $F$-statistics $(f)$ & Sig. $(p)$ \\
\hline \multicolumn{6}{|l|}{ Before-selection } \\
\hline Between groups & 10.408 & 3 & 3.469 & 7.965 & 0.000 \\
\hline Within groups & 237.386 & 545 & 0.436 & - & - \\
\hline Total & 247.794 & 548 & - & - & - \\
\hline \multicolumn{6}{|l|}{ During-selection } \\
\hline Between groups & 6.965 & 3 & 2.322 & 6.091 & 0.000 \\
\hline Within groups & 203.530 & 534 & 0.381 & - & - \\
\hline Total & 210.495 & 537 & - & - & - \\
\hline \multicolumn{6}{|l|}{ Development } \\
\hline Between groups & 4.154 & 3 & 1.385 & 2.633 & 0.049 \\
\hline Within groups & 271.368 & 516 & 0.526 & - & - \\
\hline Total & 275.521 & 519 & - & - & - \\
\hline
\end{tabular}

ANOVA, analysis of variance; $d f$, degrees of freedom; MS, mean square; SS, sum of squares. 
In conclusion, it can be inferred that, in general, older respondents had a more positive perception of the measured aspects of the organisation than the younger ones.

\section{Analysis of variance for length of service}

In Table 3 , it is evident that significant differences $(p<0.05)$ were obvious between groups on before-selection (0.000), during-selection (0.000) and development (0.049). The latter is marginally significant and the researcher is performing analysis.

In Figure 2, further investigation revealed that the perceptions of engagement with the organisation on before-selection showed a steady increase with tenure. In the case of perceptions on during-selection, those with 1-5 years

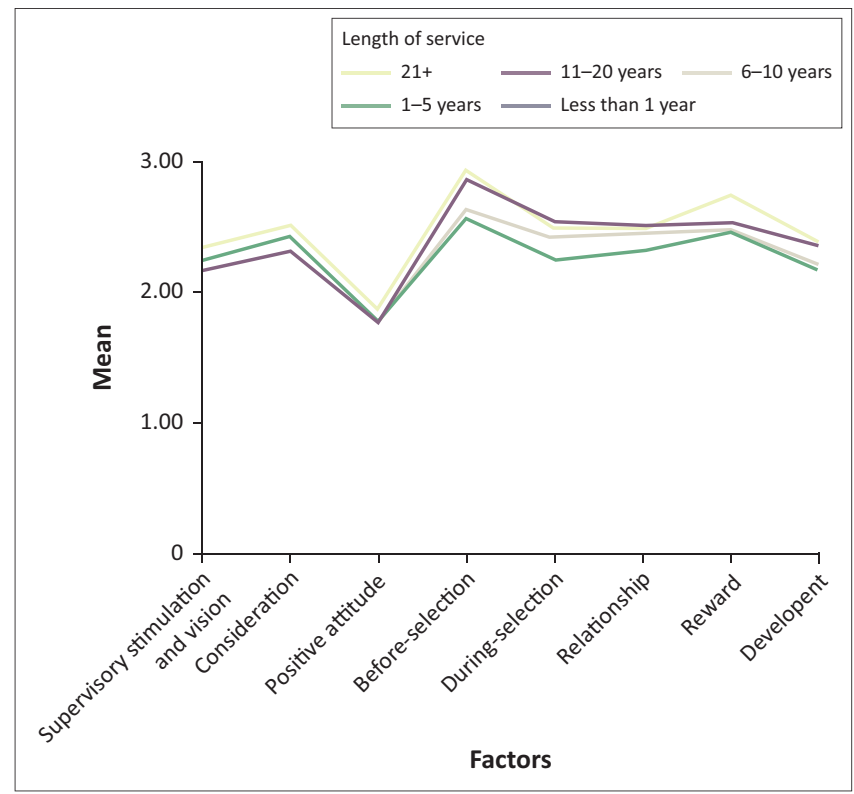

FIGURE 2: Mean plot for all eight factors for tenure groups. of experience showed a significantly lower score than those with 6-10 and 11-20 years of experience, respectively. Respondents who have been with the organisation longer seem to have a slightly more positive recollection of their engagement with the organisation on both beforeand during-selection.

\section{Analysis of variance for engineering field}

A one-way ANOVA between engineering field groups as depicted in Table 4 was conducted to compare the importance of the factors with these groups. In accordance with the $p$ scores in Table 4 , statistical significant differences $(p<0.05)$ between groups were identified for two factors (i.e. before-selection and during-selection). For these factors, the $p$ values were 0.023 and 0.003 , respectively.

In Table 5, the post hoc pairwise test was undertaken and it showed a marginal significant difference $(p<0.05)$ only between electrical and mechanical engineers for the beforeselection sub-factor. Electrical engineers had a slightly more positive perception than mechanical engineers did. The same pattern was found for the during-selection factor.

\section{Analysis of variance for educational levels}

A one-way ANOVA between educational level groups was conducted to compare the importance of the factors with these groups. None of the groups showed statistically significant difference because all the $p$ values are higher than 0.05 .

\section{Analysis of variance for managerial levels}

A one-way ANOVA between managerial levels as depicted in Table 6 was conducted to compare the groups on the sub-factors. In Table 6, a statistical significant difference $(p<0.05)$ between groups was identified for four sub-factors

TABLE 4: Analysis of variance comparison between engineering field groups.

\begin{tabular}{lcccc}
\hline ANOVA & SS & $d f$ & MS & S-statistics $(f)$ \\
\hline Before-selection & & & & \\
Between groups & 4.481 & 3 & 1.494 & 3.216 \\
Within groups & 236.402 & 509 & 0.464 & - \\
Total & 240.883 & 512 & & - \\
During-selection & & 3 & 1.809 & - \\
Between groups & 5.426 & 501 & 0.390 & - \\
Within groups & 195.300 & 504 & - & - \\
Total & 200.726 & 0.003 & - \\
\hline
\end{tabular}

ANOVA, analysis of variance; $d f$, degrees of freedom; MS, mean square; SS, sum of squares.

TABLE 5: Multi-comparison tests between engineering fields.

\begin{tabular}{|c|c|c|c|c|c|c|}
\hline \multicolumn{2}{|c|}{ Dependent variable } & \multirow{2}{*}{$\begin{array}{c}\text { Mean } \\
\text { difference (I-J) }\end{array}$} & \multirow[t]{2}{*}{ Std. error } & \multirow[t]{2}{*}{ Sig. } & \multicolumn{2}{|c|}{$95 \%$ confidence interval } \\
\hline & & & & & Lower bound & Upper bound \\
\hline \multicolumn{7}{|c|}{ Before-selection } \\
\hline Electrical & Mechanical & $0.20726 \dagger$ & 0.07235 & 0.043 & 0.0043 & 0.4102 \\
\hline Mechanical & Electrical & $-0.20726 \dagger$ & 0.07235 & 0.043 & -0.4102 & -0.0043 \\
\hline \multicolumn{7}{|c|}{ During-selection } \\
\hline Electrical & Mechanical & $0.23596 \dagger$ & 0.06679 & 0.006 & 0.0486 & 0.4233 \\
\hline
\end{tabular}

$\dagger$, The mean difference is significant at the 0.05 level. 
TABLE 6: Analysis of variance comparison between managerial level groups.

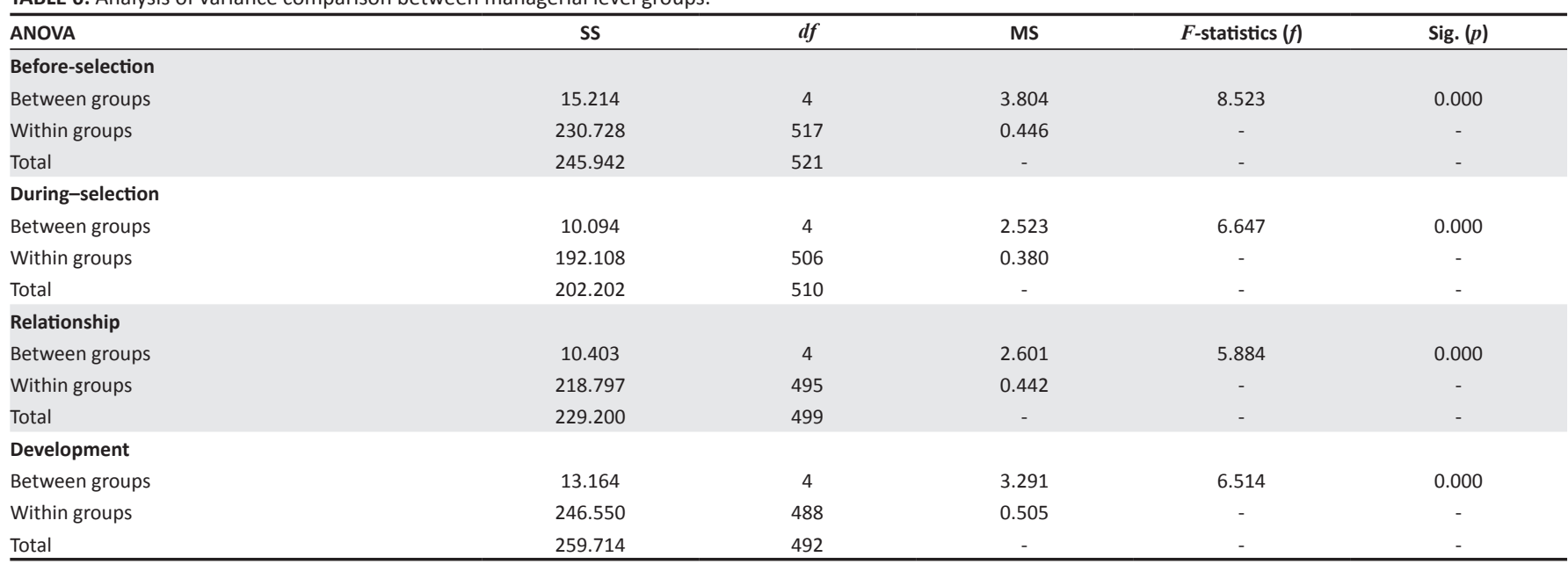

ANOVA, analysis of variance; df, degrees of freedom; MS, mean square; SS, sum of squares.

TABLE 7: Multi-comparison tests between managerial level groups.

\begin{tabular}{|c|c|c|c|c|c|c|}
\hline \multirow[t]{2}{*}{ Dependent variable } & & \multirow{2}{*}{$\begin{array}{c}\text { Mean } \\
\text { difference (I-J) }\end{array}$} & \multirow[t]{2}{*}{ Std. error } & \multirow[t]{2}{*}{ Sig. } & \multicolumn{2}{|c|}{$95 \%$ confidence interval } \\
\hline & & & & & Lower bound & Upper bound \\
\hline \multicolumn{7}{|l|}{ Before-selection } \\
\hline Senior manager & Engineer & $0.56874 \dagger$ & 0.13408 & 0.001 & 0.1543 & 0.9832 \\
\hline Middle manager & & $0.33313 \dagger$ & 0.07451 & 0.001 & 0.1028 & 0.5635 \\
\hline Senior engineer & & $0.26791 \dagger$ & 0.07955 & 0.024 & 0.0220 & 0.5138 \\
\hline \multirow[t]{3}{*}{ Engineer } & Senior manager & $-0.56874 \dagger$ & 0.13408 & 0.001 & -0.9832 & -0.1543 \\
\hline & Middle manager & $-0.33313 \dagger$ & 0.07451 & 0.001 & -0.5635 & -0.1028 \\
\hline & Senior engineer & $-0.26791 \dagger$ & 0.07955 & 0.024 & -0.5138 & -0.0220 \\
\hline \multicolumn{7}{|l|}{ During-selection } \\
\hline Middle manager & Engineer & $0.35191 \dagger$ & 0.06954 & 0.000 & 0.1369 & 0.5669 \\
\hline Engineer & Middle manager & $-0.35191 \dagger$ & 0.06954 & 0.000 & -0.5669 & -0.1369 \\
\hline \multicolumn{7}{|l|}{ Relationship } \\
\hline Middle manager & Engineer & $0.35780 \dagger$ & 0.07615 & 0.000 & 0.1223 & 0.5933 \\
\hline Engineer & Middle manager & $-0.35780 \dagger$ & 0.07615 & 0.000 & -0.5933 & -0.1223 \\
\hline Middle manager & Engineer & $0.37411 \dagger$ & 0.08163 & 0.000 & 0.1217 & 0.6265 \\
\hline Engineer & Middle manager & $-0.37411 \dagger$ & 0.08163 & 0.000 & -0.6265 & -0.1217 \\
\hline
\end{tabular}

$\dagger$, The mean difference is significant at the 0.05 level.

(i.e. before-selection, during-selection, relationship and development).

In Table 7, a post hoc pairwise test was undertaken and it showed statistical significant differences $(p<0.05)$ between different managerial levels. Looking at the statistical significant differences on the before-selection sub-factor, it would appear that the engineers differed significantly from senior managers, senior engineers and middle managers, respectively. Inspection of the mean scores shows that, in all cases, engineers had a lower score than the other groups and thus had a relatively more negative attitude on this factor.

For during-selection, relationship and development, only middle managers and engineers showed significant differences. In all cases, the mean value of engineers was lower than that of middle management.

\section{Correlation}

Leedy and Ormrod (2015) define correlation as a statistical process by which researchers discover whether two or more variables are in some association with one another. Thus, the resulting statistics is called correlation coefficient, which is a number between -1 and +1 . These scholars contend that a number close to either +1 or -1 (i.e. +0.89 or -0.76 ) indicates a strong correlation. In contrast, a number close to 0 (i.e. +0.15 or -0.22 ) indicates a weak correlation. It is also true that correlation in the middle range (i.e. 0.40 and 0.50 , positive or negative) indicates a moderate correlation.

Using this guideline, correlations were mostly of a small practical effect, except for those highlighted in bold in Table 8, which were of moderate effect size. It is thus clear that transformational leadership only correlated significantly with the overall retention score, as well as with relationship and development, two of the retention sub-scales.

In Table 9, the correlation is statistically significant $(p<0.05)$ and the correlation value is 0.379 . This means that there is a statistical significant positive correlation between talent acquisition and talent retention. In other words, as one variable improves, the same happens to the other one. 


\section{Mediation}

According to Hayes (2009), mediation is a sequence of causal relations by which variable $X$ exerts its effect on variable $Y$ by influencing intervening variables.

TABLE 8: Correlation between all eight sub-factors.

\begin{tabular}{|c|c|c|c|}
\hline Correlations & $\begin{array}{l}\text { Supervisory } \\
\text { stimulation } \\
\text { and vision }\end{array}$ & Consideration & Positive attitude \\
\hline \multicolumn{4}{|l|}{ Spearman's Rho } \\
\hline \multicolumn{4}{|l|}{ Before-selection } \\
\hline Correlation coefficient & $0.181 * *$ & $0.134^{* *}$ & $0.115^{* *}$ \\
\hline Sig. (2-tailed) & 0.000 & 0.002 & 0.007 \\
\hline \multicolumn{4}{|l|}{ During-selection } \\
\hline Correlation coefficient & $0.124 * *$ & $0.106 *$ & $0.126 * *$ \\
\hline Sig. (2-tailed) & 0.004 & 0.014 & 0.003 \\
\hline \multicolumn{4}{|l|}{ Relationship } \\
\hline Correlation coefficient & $0.406 * *$ & $0.356 * *$ & $0.383 * *$ \\
\hline Sig. (2-tailed) & 0.000 & 0.000 & 0.000 \\
\hline \multicolumn{4}{|l|}{ Reward } \\
\hline Correlation coefficient & $0.123 * *$ & $0.155^{* *}$ & $0.126 * *$ \\
\hline Sig. (2-tailed) & 0.006 & 0.000 & 0.004 \\
\hline \multicolumn{4}{|l|}{ Development } \\
\hline Correlation coefficient & $0.443 * *$ & $0.414 * *$ & $0.392 * *$ \\
\hline Sig. (2-tailed) & 0.000 & 0.000 & 0.000 \\
\hline \multicolumn{4}{|l|}{ Talent acquisition } \\
\hline Correlation coefficient & 0.176 & 0.137 & 0.153 \\
\hline Sig. (2-tailed) & 0.000 & 0.001 & 0.000 \\
\hline \multicolumn{4}{|l|}{ Talent retention } \\
\hline Correlation coefficient & $0.438 * *$ & $0.414 * *$ & $0.414 * *$ \\
\hline Sig. (2-tailed) & 0.000 & 0.000 & 0.000 \\
\hline
\end{tabular}

$* *$, The mean difference is significant at the 0.01 level (2-tailed)

TABLE 9: Correlation between talent acquisition and talent retention.

\begin{tabular}{lcc}
\hline Spearman's Rho & Talent acquisition & Talent retention \\
\hline Talent acquisition & & $\mathbf{0 . 3 7 9 * *}$ \\
Correlation coefficient & 1.000 & 0.000 \\
Sig. (2-tailed) & - & 530 \\
$N$ & 553 & \\
Talent retention & & 1.000 \\
Correlation coefficient & $\mathbf{0 . 3 7 9 * *}$ & - \\
Sig. (2-tailed) & 0.000 & 530 \\
$N$ & 530 &
\end{tabular}

**, Correlation is significant at 0.01 level (2-tailed).
A bootstrapping test was conducted to determine the mediating influence of transformational leadership between talent acquisition and talent retention. In measuring the mediation role of transformational leadership between talent acquisition and retention, Baron and Kenny (1886) model was used. The variables that were measured are depicted below, where $\mathrm{X}=$ Talent Acquisition, $\mathrm{Y}=$ Talent Retention and $\mathrm{M}=$ Transformational Leadership.

Figure 3 illustrates the effect transformational leadership ( $\left.c^{\prime}\right)$ has on the relationship between talent $X$ and $Y$. The effects are discussed in Table 10.

The number of bootstrap samples for biasness-corrected bootstrap confidence intervals is 5000 and the level of confidence for all confidence intervals in output is 0.95 .

Step 1: This step establishes the direct effect of $X$ on $Y$. In an intervening variable model, variable $X$ is hypothesised to exert an effect on an outcome variable $\mathrm{Y}$ through one or more intervening variables, sometimes called mediators. This represents path $\mathrm{c}$ in the model in Figure 3. In step 1 of the mediation model, the talent acquisition on talent retention, ignoring the mediator, was significant $(\mathrm{b}=0.3444$ and $p=0.000)$.

Step 2: Next, it needed to be shown that the independent variable is correlated with the mediator. This step essentially involves treating the mediator as if it were an outcome

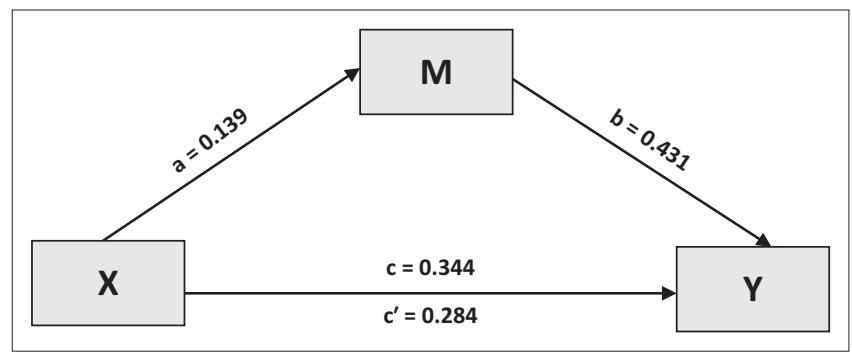

FIGURE 3: A simple mediation model.

TABLE 10: Leadership mediation model.

\begin{tabular}{|c|c|c|c|c|c|c|}
\hline$R$ & $R^{2}$ & MSE & $F$ & df1 & df2 & $p$ \\
\hline \multicolumn{7}{|c|}{ Outcome: Transformational leadership } \\
\hline \multicolumn{7}{|l|}{ Model summary } \\
\hline 0.1526 & 0.0233 & 0.2556 & 2.5870 & 1.0000 & 528.0000 & 0.0004 \\
\hline Model & Coefficient & Se & $T$ & $p$ & LLCI & ULCI \\
\hline Constant & 1.7460 & 0.1036 & 16.8601 & 0.0000 & 1.5426 & 1.9495 \\
\hline Talent acquisition & 0.1396 & 0.0393 & 3.5478 & 0.0004 & 0.0623 & 0.2126 \\
\hline \multicolumn{7}{|l|}{ Outcome: Talent retention } \\
\hline \multicolumn{7}{|l|}{ Model summary } \\
\hline 0.5507 & 0.3033 & 0.1947 & 114.7179 & 2.0000 & 527.0000 & 0.0000 \\
\hline Model & Coefficient & Se & $T$ & $p$ & LLCl & ULCI \\
\hline Constant & 0.7679 & 0.1121 & 6.8500 & 0.0000 & 0.5477 & 0.9882 \\
\hline Transformational Leadership & 0.4312 & 0.0380 & 11.3513 & 0.0000 & 0.3565 & 0.5058 \\
\hline Talent acquisition & 0.2842 & 0.0348 & 8.1795 & 0.0000 & 0.2160 & 0.3525 \\
\hline \multicolumn{7}{|c|}{ Normal theory of indirect effect } \\
\hline Effect & & & & $Z$ & $P$ & \\
\hline 0.0602 & & & & 3.3744 & 0.0007 & Sobel \\
\hline
\end{tabular}

Note: The bold values depict a strong effect of $y$ on $x$ between sub-factors.

MSE, mean square error; LLCI, lower level of confidence interval; SE, standard error; ULCI, upper level of confidence interval. 
variable and represents path a above. Step 2 showed that the regression talentacquisition on the mediator, transformational leadership, was also significant $(\mathrm{b}=0.139$ and $p=0.000)$.

Step 3: Now, it must be demonstrated that the mediator affects the outcome variable (estimate and test path $\mathbf{b}$ ). However, it needed to be controlled for the independent variable. In this case, the relationship between transformational leadership and talent retention is significant $(\mathrm{b}=0.431$ and $p=0.000)$, controlling for talent acquisition.

Step 4: To establish path $c^{\prime}$, namely that $M$ mediates the $X-Y$ relationship, the effect of $X$ on $Y$ controlling for $M$ should be zero. This would mean that there is complete mediation. This analysis revealed that, controlling for the mediator (transformational leadership), talent acquisition was still a significant predictor of talent retention $(b=0.284$ and $p=0.000)$, which suggests partial mediation. Satisfying all four conditions provides evidence for complete mediation, whereas satisfying the first three conditions indicates partial mediation.

In other words, if the effect of $X$ on $Y$ is reduced when the mediator is included $\left(c^{\prime}<c\right)$, then the direct effect is said to be partially mediated. The B coefficient for $\mathrm{c}$ is 0.244 and for path $c^{\prime}$, it is 0.284 . The effect is thus reduced. This is confirmed by the indirect effect in the output. Zero does not fall within the confidence intervals of the Beta coefficient $\mathrm{BCi}=0.269$, 0.097; therefore, mediation can be assumed.

Significant mediation ( $\mathrm{z}=060$ and $p=0.001)$ was found: transformational leadership mediated the relationship between talent acquisition and talent retention. In essence, this implies that any changes in either the improvement or deterioration in transformational leadership will increase the level of engineers' desire to remain in the organisation or leave, regardless of the improvement in the talent acquisition levels.

\section{Discussion}

The purpose of this study is to analyse transformational leadership, talent acquisition and talent retention of engineers at Eskom by investigating the demographic differences (gender, age, length of service, engineering field, education levels and managerial levels), the relationships between the variables and transformational leadership as the mediating variable between talent acquisition and talent retention of engineers.

In a study by Govender, Garbharran and Loganathan (2013) on leadership style and job satisfaction, the results showed no statistically significant difference in the perceptions of overall transformational leadership and its dimensions and the biographical variables of gender, grade and age. In the same study, the results of the $t$-test reflected no significant difference $(p>0.05)$ between males and females about transformational leadership as well as its dimensions in all instances. These results by Govender et al. (2013) confirm what has been found in the present study on gender, but it is inconsistent on age. In another study by Seloane (2010), concurring with the current study, as regards to age groups, he found that there is a statistical significant difference on perception about transformational leadership style 'Modelling the way' $(p<0.05)$ and 'Enabling others to act' $(p<0.01)$

In another study by Sun and Wang (2017) and consistent with the current study, these two scholars established that transformational leadership could directly lower an employee's intention to leave the organisation. Tse et al. (2013) explored the relationship between transformational leadership and turnover intention and the mediation role of affective commitment. This study found that transformational leadership has a negative relationship with turnover intention and that affective commitment mediates it. In another study by Maaitah (2018) on the 'Role of Leadership Style on Turnover Intention', transformational leadership was found to be negatively and significantly correlated with turnover intention. This finding is consistent with the findings of this study where transformational leadership is found to statistically significantly influence talent retention.

In a study by Were (2015), it was revealed that the relationship between transformational leadership style and talent management is statistically significant $(p=0.000)$ and positively ( $\beta=0.303$ ) related. As mentioned earlier, talent acquisition is part of the talent management process. Therefore, to a certain extent, I can state that talent acquisition in the study by Were (2014) could be said to be statistically significant to transformational leadership. These results are therefore consistent with the results of the present study where it was established from a regression analysis viewpoint that transformational leadership statistically significantly correlates with talent acquisition.

In agreement with the present study, Shabane, Schultz and Van Hoek (2017) revealed that transformational leadership played a mediating role in the relationship between satisfaction with remuneration and intention to stay. It is the contention by Coomber and Barriball (2006) that satisfaction with remuneration and intention to stay are factors that play a positive role in enhancing the retention employees in organisations.

\section{Limitations}

The following limitations were encountered in this study:

- From a designation perspective, the following limitations were encountered during this study:

- Few senior managers participated in this study.

- In addition, few senior engineers participated in this study.

- Less than expected engineers responded to the questionnaire. 
- This study was performed only from a quantitative approach perspective and follow-up questions could not be posed to respondents.

- This study could have included the human resources practitioners because they are to a certain extent the custodian of the human resources policies and practices.

\section{Recommendations}

Based on this study, the following recommendations are suggested to address the challenge of attracting and retaining engineers at Eskom:

- Future research should also be conducted on other scarce skilled employees (i.e. artisans, technicians and technologist) because the challenge in attraction and retention is spread on all these employees.

- Engineers should be allowed to be creative and innovative so that they stay challenged and engaged in the work they know best. This will improve their retention and thereby the quality of their work. Likewise, the relationship between engineers, managers and leaders should be kept intact to reduce turnover. It is widely known in the leadership literature that employees leave their managers and not the organisation because of poor relations between employees and their supervisors.

- A similar study should be conducted but with the involvement of the human resources practitioners from a talent acquisition and retention perspective. The findings of this study could help Eskom and other organisations improve their selection processes for leaders who display strengths in transformational leadership attributes in order to benefit from it. For example, they could use selection tools to assess transformational leadership attributes to identify leaders who have the potential to become effective transformational leaders.

- Managers and leaders who manage and lead these engineers should be trained on the application of transformational leadership philosophy to effectively address attraction and retention challenge of engineers.

- Training on the application of transformational leadership philosophy should be extended to non-managerial engineers so that by the time they are promoted to leadership positions, they already possess the transformational leadership skills.

- Another similar study should be conducted but should include both quantitative and quality approaches to allow for a balanced view.

\section{Conclusion}

The main aim of this study was to determine whether transformational leadership is a mediator in the relationship between talent acquisition and retention of engineers. The results evidently showed that there is statistically significant mediation between acquisition and retention of engineers and transformational leadership. The results of this study could assist the leadership at Eskom to improve the attraction and retention of engineers by implementing effective transformational leadership development philosophy and programmes. The more the transformational leadership philosophy is embraced at Eskom, the better it can attract and retain its engineers. This may result in improved performance of Eskom in generating, distributing and transmitting electricity throughout South Africa and its neighbouring countries.

\section{Acknowledgements}

Dr Liezel Korf is acknowledged for her assistance with the statistical analysis.

\section{Competing interests}

The authors have declared that no competing interests exist.

\section{Authors' contributions}

All authors contributed equally.

\section{Ethical consideration}

Tshwane University of Technology, FREC2015/FR/09/010MS (2).

\section{Funding information}

This research received public funding from National Research Foundation in South Africa.

\section{Data availability statement}

Data sharing shall be available whenever is needed.

\section{Disclaimer}

The views and opinions expressed in this article are those of the authors and do not necessarily reflect the official policy or position of any affiliated agency of the authors.

\section{References}

Avolio, B.J., \& Bass, B.M. (2004). Multi-factor leadership questionnaire. Manual and sample letter (3rd edn.). Redwood City, CA: Mind Garden.

Baron, R.M., \& Kenny, D.A. (1986). The moderator-mediator variable distinction in social psychological research: Conceptual, strategic, and statistical considerations. Journal of Personality \& Social Psychology, 51, 1173-1182.

Bass, B.M., \& Avolio, B.J. (Eds.). (1996). Improving organisational leadership through transformational leadership. London: Sage.

Better, M. (2015). Retention of engineers: Putting compensation and learning and development to good use. Retrieved from http://www.optforce.com/wp-content/ uploads/Engineer-Retention-CaseStudy.pdf

Bless, C., Higson-Smith, C., \& Sithole, S.L. (2014). Fundamentals of social research methods: An African perspective (5th edn.). Cape Town: Juta.

Burns, J.M (1978) Leadership. N.Y: Harper and Row.

Call, M.L., Nyberg, A.J., \& Thatcher, S. (2015). Stargazing: An integrative conceptual review, theoretical reconciliation, and extension for star employee research. Journal of Applied Psychology, 100(3), 623-640. https://doi.org/10.1037/ a0039100

Chartered Institute of Personnel Development. (2018). Talent management: Understand the changing context and benefits of talent management, and the key features of a talent management strategy. Retrieved from https://www.cipd. co.uk/knowledge/strategy/resourcing/talent-factsheet 
Chatterji, A., \& Patro, A. (2014). Dynamic capabilities and managing human capital. Academy of Management Perspectives, 28(4), 395-408. https://doi.org/10.5465/ amp.2013.0111

Coomber, B., \& Barriball, K.L. (2006). Impact of job satisfaction components on intent to leave and turn over for hospital-based nurses: A review of the research literature. International Journal of Nursing Studies, 44, 297-314.

Crispin, G., \& Mehler, M. (2011). The candidate experience: What they say it is; What it really is; and, What it can be. Retrieved from http://www.careerxroads.com/ colloquium/files/TheCandidateExperienceMonograph.pdf

Devi, B.R., \& Banu, P.V. (2014). Introduction to Recruitment. SSRG International Journal of Economics and Management Studies, 1(2), 5-8.

Dhanpat, N., Modau, F.D., Lugisani, P., Mabojane, R., \& Phiri, M. (2018). Exploring employee retention and intention to leave within a call centre. SA Journal of Human Resource Management/SA Tydskrif vir Menslikehulpbronbestuur, 16(0), a905. https://doi.org/10.4102/sajhrm.v16i0.905

Downton, J.V. (1973). Rebel leadership: Commitment and charisma in the revolutionary process. New York, NY: Free Press.

Eberly, M.B., Bluhm, D.J., Guarana, C., Avolio, B.J., \& Hannah, S.T. (2017). Staying after the storm: How transformational leadership relates to follower turnover intentions in extreme contexts. Journal of Vocational Behavior, 102(1), 72-85. https://doi.org/10.1016/j.jvb.2017.07.004

Engelen, A., Gupta, V., Strenger, L., \& Brettel, M. (2015). Entrepreneurial orientation, firm performance, and the moderating role of transformational leadership behaviors. Journal of Management, 41(4), 1069-1097. https://doi.org/10.1177/ 0149206312455244

George, C. (2015), 'Retaining professional workers: What makes them stay?', Employee Relations, 37(1), 102-121. https://doi.org/10.1108/ER-10-2013-0151

Govender, J. P., Garbharran, H. L., \& Loganathan, R. (2013). Leadership style and job satisfaction: A developing economy perspective. Corporate Ownership \& Control, 10(4-4), 390-399. http://doi.org/10.22495/cocv10i4c4art2

Hayes, A.F. (2009). Beyond Baron and Kenny: Statistical Mediation Analysis in the New Millennium. Communication Monographs, 76(4), 408-420. http://dx.doi org/10.1080/03637750903310360

Kaiser, F.H. (1970). A second generation little jiffy. Psychometrika, 35(4), 401-415. https://doi.org/10.1007/BF02291817

Kaur, B., \& Mohindru, \& Pankaj. (2013). Antecedents of turnover intentions: A literature review. Global Journal of Management and Business Studies, 3(10), 1219-1230.

Kehoe, R.R., \& Tzabbar, D. (2015). Lighting the way or stealing the shine? An examination of the duality in star scientists' effects on firm innovative performance. Strategic Management Journal, 36(5), 709-727. https://doi.org/ $10.1002 / \mathrm{smj} .2240$

Khorshid, S., \& Pashazadeh, A. (2014). The impact of transformational leadership on organizational learning capabilities with respect to the mediating role of organizational intelligence. Transformational Leadership Journal, 11(1), 1-28.

Kibui, A. W., \& Kanyiri, J. W. (2014). Role of Talent Retention on Generation Y Employees in Kenya's State Corporations: Empirical Review. International Journal of Applied Research and Studies, 3(3), 1-14.

Leedy, P.L., \& Ormrod, J.E. (2015). Practical research: Planning and design (11th edn.). London: Pearson Education.

Lievens, F., Van Giet, P., \& Coetsier, P. (1997). Identification of transformational leadership qualities: An examination of potential biases. European Journal of Work and Organizational Psychology, 6(4), 415-430. https://doi.org/10.1080/ 135943297399015
Louw, L., Muriithi, S.M., \& Radloff,S. (2017). The relationship between transformational leadership and leadership effectiveness in Kenyan indigenous banks. SA Journal of Human Resource Management/SA Tydskrif vir Menslikehulpbronbestuur, 15(7), a935. https://doi.org/10.4102/sajhrm.v15i0.935

Martin, A., 2007, Employee perception of organisational commitment, job satisfaction and turnover intentions in a post-merger institution. Retrieved from https:// ujdigispace.uj.ac.za/bitstream/handle/10210/552/A_Martin_MCom_Final. pdf?sequence $=1$ \&isAllowed $=y$

Meyer, T. (2016). Talent framework and issues in talent management. In T. Meyer (Ed.), Shaping Africa's talent: Enabling Africa's potential. Randburg: KR Publishing.

Mittal, S., \& Dhar, R.L. (2015). Transformational leadership and employee creativity: Mediating role of creative self-efficacy and moderating role of knowledge sharing. Management Decision, 53(5), 894-910. https://doi.org/10.1108/MD-07-20140464

Naidoo, V., Abarantyne, I., \& Rugimbana, R. (2019). The impact of psychological contracts on employee engagement at a university of technology. SA Journal of Human Resource Management/SA Tydskrif vir Menslikehulpbronbestuur, 17(1) a1039. https://doi.org/10.4102/sajhrm.v17i0.1039

Peers, S. (2018). Statistics on women in engineering. Retrieved from http://www. researchgate.net/publication/330999061 Women in Engineering_Statistics version_January_2018

Rivera, M. (2012). Talent acquisition: A definition. Seamless workforce. Retrieved from http://blog.yoh.com/2011/05/talent-acquisition-adefinition.htm

Seloane, M. P. (2010). The relationship between transformational leadership and organisational culture (Unpublished master's thesis), University of South Africa, South Africa.

Sequeira, A., Attupuram, P.J., \& Gopalakrishnan, S. (2015). Talent acquisition process in a multinational company: A case study. Retrieved from https://ssrn.com/ abstract=2708086 or https://doi.org/10.2139/ssrn.2708086

Shabane, Z.W., Schultz, C.M., \& Van Hoek, C.E. (2017). Transformational leadership as a mediator in the relationship between satisfaction with remuneration and the retention of artisans in the military. SA Journal of Human Resource Management/ SA Tydskrif vir Menslikehulpbronbestuur, 15(1), a923. https://doi.org/10.4102/ sajhrm.v15i0.923

Singh, S., \& Peers, S. (2019). Where are women in engineering labour market? A crosssectional study. International Journal of Gender, Science and Technology, 11(1) 203-231. Retrieved from http://genderandset.open.ac.uk

Sinha, C., \& Sinha, R. (2012). Factors affecting employee retention: A comparative analysis of two organizations from heavy engineering industry. European Journa of Business and Management, 4(3), 145-162.

Smith, K.N., \& Gayles, J.G. (2018). 'Girl Power': Gendered academic and workplace experiences of college women in engineering. Open Access Journal, 7(1), 1-23. https://doi.org/10.3390/socsci7010011

Sun, R., \& Wang, W. (2017). Transformational leadership, employee turnover intention, and actual voluntary turnover in public organizations. Public Management Review, 19(8), 1124-1141. https://doi.org/10.1080/14719037.2016.1257063

Tse, H.H.M., Huang, X., \& Lam, W. (2013), Why does transformational leadership matter for employee turnover? A multi-foci social exchange perspective. The Leadership Quarterly Journal, 24, 763-776.

Welman, C., Kruger, F., \& Mitchell, B. (2011). Research methodology (3rd edn.). Cape Town: Oxford University Press.

Were, P.O. (2014). Effects of Organization Culture on Change Management: A case of the Vocational Training Centre for the Blind and Deaf Sikri. European Journal of Business and Management, 6(34), 204-214. https://iiste.org/Journals/index.php/ EJBM/article/view/17157. 